\begin{tabular}{lc|}
\hline UAD & ADJES (Ahmad Dahlan Journal of English Studies) \\
VOL 8, No. 1, 17-24 \\
$\begin{array}{l}\text { Universitas } \\
\text { Ahmad Dahlan }\end{array}$ \\
https://doi.org/10.26555/adjes.v8i1.17583
\end{tabular}

\title{
An Analysis of Students' Difficulties in Mastering Phrasal Verbs
}

\author{
${ }^{1}$ Baiq Suprapti Handini, ${ }^{2}$ Muhammad Husnu, ${ }^{3}$ Marzuki \\ Email: 1'sue.anh14@gmail.com, ${ }^{2}$ oesnoedotuu@gmail.com, ${ }^{3}$ gustioky79@gmail.com \\ Hamzanwadi University, Selong, Indonesia
}

\section{ARTICLE INFO}

Article history

Received: 9 August 2020

Revised: 2 March 2021

Accepted: 10 March 2021

Keywords

students' difficulties

mastering phrasal verb

\section{ABSTRACT}

This research aimed at knowing about an analysis of student's difficulties in mastering phrasal verb. This research is descriptive qualitative research. The subject of research was the students of Hamzanwadi University which consisted of 10 students. In this research, observation, questionnaire, and semi structured interview, were used for collecting data. The researcher conducted a descriptive design to analyzed and understanding people or human problems and describe the situation which is related to the students' problem when using phrasal verb. The finding revealed that the student's in Hamzanwadi University get difficulties in mastering phrasal verb. Otherwise, based on the result of observation, questionnaire, and interview, were clarified that students in Hamzanwadi University faced many problems, such as lack of vocabulary, less understanding of phrasal verb and difficulty to produce sentences with phrasal verbs.

This is an open access article under the CC-BY-SA license.

\section{Introduction}

Language is a vehicle of expression or communication and it has an important rule for human life (Mazari \& Derraz, 2015). By using language, the people would express their ideas, emotion, desire, and it was used as a medium to interactive each other to fulfill their daily needs (Rosenberg \& Chopra, 2015). English as a mean of communication plays an important role. It can be seen in the newspapers that vacancies need person who master English well (Jiang et al., 2019). In learning English, there are four skills that should be mastered by the students, those are listening, speaking, reading, and writing (Muthmainnah, et al., 2019). Beside the skills of English, the aspect of language must be mustered by the students, one of those is vocabulary (Susanto, 2017). Phrasal verb is one of the features in the English language which has it is own pattern (Rodríguez-Puente, 2019). Phrasal verbs are commonly found in the grammar course, and sometimes they also appear in vocabulary textbook (Durna \& Güneş, 2020). Phrasal verbs are 
acknowledged as one of the grammatical problems in academic context. While they are totally understood in informal oral skill, they are assumed to have no reputation in official academic writing. Instances of phrasal verb in formal registers are often seen as stylistic inappropriateness, for which students' work is marked down. Thus, when it comes to formal writing, students across the world are explicitly instructed to replace phrasal verb with one word, mostly Latinate, equivalents. Zarifi \& Mukundan (2013) states that phrasal verbs are ubiquitous. English phrasal verbs consist of a verb paired with a particle that is homophonous with an English preposition (Siregar, 2020). The verb and its particle are written as separate words in the orthography, and the Phrasal verb shares similarities, such as transitivity and irregularity, with the single wordword which the verb part of the Phrasal verb resembles and from which in presumably originates.

Furthermore, Garnier \& Schmitt (2015) state that phrasal verbs carry a large number of meanings and function. These meanings often cannot be conveyed by a single word equivalent or may carry connotation that their single word equivalent does not have. More importantly, using phrasal verbs is crucial to fluent English and to sounding native (Götz, 2013). However, Omidian et al. (2019) state that phrasal verb may be seen unnatural construction for some learner whose first language lacks such a structure. Garnier \& Schmitt (2015) says that in studying English vocabulary, the student should know a lot of parts of vocabulary particularly about "phrasal verb" and the researcher found in the preliminary study that students of Hamzanwadi University were confused in understanding phrasal verb. Learning phrasal verb is important for student because number of phrasal verbs become a part of materials that is presented and taught in their course books (Litvinov et al., 2017).

Speakers of English tend to use phrasal verbs and idioms (especially in informal English conversations), instead of one word 11 since sometimes, there is no other precise word to say it (Rodríguez-Puente, 2019). For instance, it sounds funny to say "enter" to substitute "come in" in response to the door knocked. It is more precise to say, "the tank blew up" instead of saying "the tank exploded". The combination of verb + particle has syntactic features. Before the researcher discusses further such combinations, it is better for us to know the definition of verb and particle.

Generally, Phrasal verb are defined as a combination of two lexical element: a verb and discussed within the literature of Phrasal verb, particularly on the grammatical status of the particle in Phrasal verb construction: whether a particle must be an adverbial particle (example : out, up, down ) as in a look up, break down; or whether in could also include preposition (with, after, into ) as in deal with, look after, run into (Strong \& Boers, 2019).

Alwasilah as cited in Azmar (2019) gives restrictions of phrasal verbs. First, the combination is limited to certain particle such as down, on, off, in, out, up. Although there is no restriction on the verbs, however, the most common verbs are those simple and short ones such as put, take, get, 
and make. Second, the combination is not freely formed; It is a collocation restriction. The restriction is clearly seen when we substitute the particle with its antonym. We can say "put up with it", but we cannot say "put down with it". The words "give out" and "carry off" are not the antonym of "give in" and "carry on". Lastly, combination usually can be substituted with one-word verb. However, their meaning is not exactly the same, e.g., "carry on" means continue, "put up with" means 'tolerate', put off means 'postpone', etc.

The researcher gives some limitations of this research. This topic only focuses on the analysis of why students get difficult in using phrasal verb. Observing the research process in order to find the difficulties in mastering phrasal verb. The researchers observe, investigate, and analyze the data of students in Hamzanwadi University. The purpose of this study is to find out difficulties faced by the student in mastering phrasal verb and to describes the student's ability in mastering phrasal verb.

The relevant study of this research was thesis by Kamarudin (2013) which examines the level of understanding and use of English phrasal verbs amongst Malaysian learners of English. It is generally agreed that idiomatic expressions, including phrasal verbs, present great difficulties for language learners. Various reasons have been highlighted, which include the nature of Phrasal Verbs themselves, as well as crosslinguistic factors. Two different types of methodology - survey and corpus work - are used to find answers to the research questions. In well as their views on the vocabulary contents presented in school textbooks. The result of research Using methodology survey and corpus work in school textbooks it was effective to improves learner Results, in addition to learners' proficiency level and gender.

\section{Method}

The design of this study was qualitative descriptive research. Nassaji (2015) states that "Descriptive research is the research involving the collection of data for the purpose of describing existing conditions. This research conducted in a descriptive design. Descriptive research does not aim at a testing hypothesis, but only to describe variables, phenomenon or situations. A descriptive study is one in which information is collected without changing the environment. Descriptive research examines a phenomenon, group of people, idea or theory with a particular focus on facts and conditions of the subject. The goal of a descriptive thesis is to collect factual evidence and information that gives your reader a comprehensive perception of your subject and it should be unbiased (Tracy, 2019). The descriptive design used to describe the phenomenon of the phrasal verb errors of students. Descriptive research is research that involves gathering data that describe events and then organizes, tabulates, depicts, and describes the data collection (Juliardi et al., n.d.).

The setting of this research was University of Hanzanwadi, Selong. The participants of this 
research were 5th semester students from Hamzanwadi University. The researchers chose the participant considering that 5th semester students are in intermediate level and that students have been learning vocabulary and grammar in previous semester.

Albuquerque et al. (2014) state that questionnaires was used to obtain information from study subjects, developing questioners was the last step in designing a study after variables of interest have been identified. By first identifying the information that is needed to answer the study objective, questions will be limited to those needed to obtain the required information. The data collected from the observation used in doing the research. In this case, the researchers ask questions comprising phrasal verbs for participant. It used semi structure interview to collect the data. Related to the interview, it was conducted by using the guideline of interview which focused to the problem of the study.

\section{Discussion}

1. Question 1: What are the Difficulties Factors Faced by the Student in Using Phrasal Verb to Arrange a Sentence?

Based on the data, the result of the questionnaire from the question 1 until question 2, It was found that student got difficulties in mastering phrasal verb because, they were confused in the meaning and never learn a phrasal verb more specifically. The question number 3 until number 5 proved that the lack of vocabulary subject meeting and less interested in conversation using phrasal verb could influence the lack of student phrasal verb mastery. The question 6 showed that the students were really less in reading phrasal verb related books, news, and articles. For the question number 7 showed that the lecture did not always give the explanation about phrasal verb in teaching vocabulary. Finally, from the question of number 8 until 10 proved that lack of reading factors, less memorizing time of phrasal verb and never knowing the characteristic of phrasal verb made students difficult to understand the use of phrasal verb. Meanwhile, the conclusion was the students were confused in understanding the meaning of phrasal verb, lack of vocabulary subject meeting, less of phrasal verb application in conversation, and never know more specifically about phrasal verb are the most problem found in learning phrasal verb and those became the fundamental factors for the students difficulties in mastering phrasal verb. 
Table 1. Questionnaire result

\begin{tabular}{|c|c|c|c|}
\hline No & Questions & Answer & Percent \\
\hline \multirow[t]{2}{*}{1.} & \multirow{2}{*}{$\begin{array}{l}\text { Are there any problems that you will face in learning process that make } \\
\text { you feel confuse and difficult to understand phrasal verb? }\end{array}$} & YES & $80 \%$ \\
\hline & & NO & $20 \%$ \\
\hline \multirow[b]{2}{*}{2.} & \multirow[t]{2}{*}{ Have you learned about phrasal verb more specifically? } & YES & $70 \%$ \\
\hline & & NO & $30 \%$ \\
\hline \multirow[t]{2}{*}{3.} & \multirow[t]{2}{*}{ Have you made sentences using phrasal verb? } & YES & $60 \%$ \\
\hline & & NO & $40 \%$ \\
\hline \multirow[t]{2}{*}{4.} & \multirow{2}{*}{$\begin{array}{l}\text { Is the lack of lecturing time in vocabulary subject influence phrasal verb } \\
\text { mastery? }\end{array}$} & YES & $60 \%$ \\
\hline & & NO & $40 \%$ \\
\hline \multirow[t]{2}{*}{5.} & \multirow[t]{2}{*}{ Do you often use phrasal verb to communicate with each other? } & YES & $78 \%$ \\
\hline & & NO & $22 \%$ \\
\hline \multirow{2}{*}{6.} & \multirow{2}{*}{ Have you read the books of phrasal verb? } & YES & $21 \%$ \\
\hline & & NO & $79 \%$ \\
\hline \multirow[t]{2}{*}{7} & \multirow{2}{*}{$\begin{array}{l}\text { Does the lecture seldom give you explanation about phrasal verb in } \\
\text { vocabulary subject? }\end{array}$} & YES & $70 \%$ \\
\hline & & NO & $30 \%$ \\
\hline \multirow[t]{2}{*}{8} & \multirow{2}{*}{$\begin{array}{l}\text { Does the lack of reading factor become the problem to learn phrasal } \\
\text { verb }\end{array}$} & YES & $80 \%$ \\
\hline & & NO & $20 \%$ \\
\hline \multirow[t]{2}{*}{9} & \multirow[t]{2}{*}{ Do you need more times to memorize a phrasal verb? } & YES & $85 \%$ \\
\hline & & NO & $15 \%$ \\
\hline \multirow[t]{2}{*}{10} & \multirow[t]{2}{*}{ Do you know about the characteristic of phrasal verb? } & YES & $23 \%$ \\
\hline & & NO & $77 \%$ \\
\hline
\end{tabular}

2. Question 2: What is the Benefit for Lecture to Know the Difficulties of the Students and Solution to Solve the Students Problem in Phrasal Verb?

According to Brown (2001, pp 406-440) the oral proficiency scoring categories were vocabulary, grammar comprehension, fluency, pronunciation and task. These were the categories of vocabulary skill by using Brown categories of vocabulary. The data should from oral proficiency categories were $69 \%$ of students did not got a good score of vocabulary, comprehension of phrasal verbs and grammar. Which meant that students were not able to use the language accurately on normally levels pertinent to professional needs, error in the meaning of phrasal verb were quite rare. Also, they couldn't understand and got mistake in any subject of vocabulary within the range of students apply English subject with a high degree of precision of vocabulary. Moreover, they could understand any conversation within the range of interaction with each other

The majority of the students were $70 \%$ of answer, that phrasal verbs in study vocabulary and grammar comprehension is really hard to understand because of the multiple meanings. The $30 \%$ of students had difficulties in mastering phrasal verbs because of lack of vocabulary. From the reality of research, there were several solutions to overcome difficulties in mastery phrasal verb. Firstly, in phrasal verb the students must be able to make a combination between verb and particle correctly, so that avoid the mistake of the meaning in phrasal verb, especially in arrange a sentence in writing skills. However, the students in Hamzanwadi university still confuse and 
unable to apply the use of phrasal verbs properly.

(Satria, 2014) states that the benefit of lectures to know the difficulties of students before teaching phrasal verb is, the lecture could help students improving vocabulary especially for phrasal verb mastery and the lecture is also able to eradicate student concern in using phrasal verb. The solution for the lecture to solve any problems above, the lecture could using many methods and strategy such as pictures to help learners remember ,use stories to lodge Phrasal verbs in students memory, or use music and technology to discover how Phrasal verb are used, the lecture could do some matching activities in practicing phrasal verb for students, and the lecture explains to students that in may be more useful phrasal verbs in communicate every day to be able to understand the expression when they hear and able to produce phrasal verb very well. The data obtained from the result of observation was the present researcher knew that students of Hamzanwadi University of English department in understanding phrasal verbs was really inadequate especially in terms of in phrasal verbs mastery both writing skills and daily conversation, the confusing and multiple meaning in phrasal verb become dominant aspect was influence students difficulties in phrasal verb mastery.

\section{Conclusion}

There were some problems faced by students in mastering phrasal verb such as lack of vocabulary, grammatical structure of word, and misunderstanding in the meaning of phrasal verbs. Knowing the problems of the students could give the benefits for lecturers when they are teaching phrasal verb and give an effort to improve the learning of phrasal verb. The lecturers should use many methods and strategies to make students understand of phrasal verbs. The use of technology nowadays is very helpful to offer so many ways to understand English better, especially in understanding phrasal verbs.

\section{References}

Albuquerque, U. P., Ramos, M. A., de Lucena, R. F. P., \& Alencar, N. L. (2014). Methods and techniques used to collect ethnobiological data. In Methods and techniques in Ethnobiology and Ethnoecology (pp. 15-37). Springer.

Azmar, C. N. (2019). Analyzing Efl learners' difficulty in understanding phrasal verbs. UIN Ar-Raniry Banda Aceh.

Durna, F. K., \& Güneş, O. (2020). A corpus linguistics investigation into phrasal verbs in British academic spoken English. Journal of Foreign Language Education and Technology, 5(1).

Garnier, M., \& Schmitt, N. (2015). The PHaVE list: A pedagogical list of phrasal verbs and their most frequent meaning senses. Language Teaching Research, 19(6), 645-666. 
Götz, S. (2013). Fluency in native and nonnative English speech (Vol. 53). John Benjamins Publishing.

Jiang, L., Zhang, L. J., \& May, S. (2019). Implementing English-medium instruction (EMI) in China: teachers' practices and perceptions, and students' learning motivation and needs. International Journal of Bilingual Education and Bilingualism, 22(2), 107-119.

Juliardi, D., Susilawati, E., \& Bunau, E. (n.d.). An analysis of students' pronunciation mastery of dental fricative and alveolar plosive sounds. Jurnal Pendidikan Dan Pembelajaran Khatulistiwa, $8(11)$.

Litvinov, A. V, Burikova, S. A., \& Khramchenko, D. S. (2017). Phrasal verbs as learning material in Business English courses for students majoring in linguistics. A Nation's Culture Resides in the Hearts and in the Soul of Its People, 1(4), 91.

Mazari, A., \& Derraz, N. (2015). Language and culture. International Journal of Humanities and Cultural Studies, 2(2), 350-359.

Muthmainnah, M., Asrifan, A., Al Yakin, A., \& Sahabuddin, C. (2019). The use of dictogloss technique on ELT classroom: An experiment study of students listening comprehension. Proceedings of the 65th TEFLIN International Conference, 65(01).

Nassaji, H. (2015). Qualitative and descriptive research: Data type versus data analysis. Sage Publications Sage UK: London, England.

Omidian, T., Akbary, M., \& Shahriari, H. (2019). Exploring factors contributing to the receptive and productive knowledge of phrasal verbs in the EFL context. Word, 65(1), 1-24.

Rodríguez-Puente, P. (2019). The English phrasal verb, 1650-present: History, stylistic drifts, and lexicalisation. Cambridge University Press.

Rosenberg, M. B., \& Chopra, D. (2015). Nonviolent communication: A language of life: Life-changing tools for healthy relationships. PuddleDancer Press.

Satria, K. A. (2014). Students' translation quality in translating English phrasal verbs into Indonesian. Script. Bengkulu: University of Bengkulu.

Siregar, L. N. (2020). The analysis of phrasal verb usage in writing news item text in fifth semester students of English department in the academic year 2018/2019 Nommensen HKBP University.

Strong, B., \& Boers, F. (2019). The error in trial and error: Exercises on phrasal verbs. TESOL Quarterly, 53(2), 289-319.

Susanto, A. (2017). The teaching of vocabulary: A perspective. Jurnal Kata: Penelitian Tentang Ilmu Bahasa Dan Sastra, 1(2), 182-191.

Tracy, S. J. (2019). Qualitative research methods: Collecting evidence, crafting analysis, 
ADJES Vol 8. No.1 March 2021 p. 17-24

communicating impact. John Wiley \& Sons.

Zarifi, A., \& Mukundan, J. (2013). Phrasal verb combinations in corpus-based studies: A critical review. International Journal of Applied Linguistics and English Literature, 2(4), 212-217. 